\title{
John Tzetzes and the pseudo-Aristotelian Peplos in middle-Byzantium. The testimony of the Matritenses gr. 4562 and $4621^{1}$
}

\author{
Carlos A. Martins de Jesus \\ University of Coimbra, Portugal \\ Centre of Classical and Humanistic Studies $(\mathrm{CECH})$ \\ carlosamjesus@gmail.com
}

Recibido: 21-11-2015

Aceptado: 26-11-2015

\begin{abstract}
In the aftermath of my edition of the pseudo-Aristotelian Pepli Epitaphia, this paper focus on the apochrypha to those epitaphs written by John Tzetzes in the twelfth century, a group of eight elegiac couplets for those heroes he felt worthy of one, and for whom he was unable to sort an extant epitaph in the manuscript sources he had access. In order to do so, it also investigates the acknowledge and transmission of that epigrammatic corpus in Byzantine literature, besides considering the readings and deeper meaning of two codices held at the National Library of Spain (M and Md), where Constantine Lascaris copied, directly from Tzetzes, two brief anthological garlands of these components.
\end{abstract}

Keywords: Pepli epitaphia, Homer, John Tzetzes, Constantine Lascaris.

\section{RESUMEN}

Tras mi reciente edición de los pseudo-aristotélicos Pepli Epitaphia, el presente trabajo se centra en los apochrypha a dichos epitafios que compuso Juan Tzetzes en el siglo XII, un conjunto de ocho dísticos elegíacos para los héroes que consideró meritorios de tal tarea, y para quienes no pudo encontrar un epitafio conservado en las fuentes manuscritas a las que tuvo acceso. Para lograr dicho propósito, también se investiga el grado de conocimiento y la transmisión de ese corpus epigramático en la literatura bizantina, además de considerar las lecciones y el sentido mismo de dos códices guardados en la Biblioteca Nacional de España (M y Md). En ellos, Constantino Láscaris copió, directamente a partir de Tzetzes, dos breves antologías de dichos componentes.

Palabras clave: Pepli Epitaphia, Homero, Juan Tzetzes, Constantino Láscaris.

\section{CONTENTS}

1. Tzetzes, Homer and the Peplos in middle-Byzantium. 2. Textual transmission and the anthologies of $\mathbf{M}$ and Md. 3. Tzetzes' apochrypha: a compromised rewriting of Homer. 4. Conclusions.

${ }^{1}$ This paper is the result of research funded by a Postdoctoral Scholarship provided by the Fundação para a Ciência e Tecnologia (Government of Portugal, Ref. SFRH/BPD/84291/2012), in collaboration with the Project Greek manuscripts in Spain and their European context (Government of Spain, Ref. FFI2011-25805). 


\section{TZETZES, HOMER AND THE PEPLOS IN MIDDLE-BYZANTIUM}

John Tzetzes is probably the best example of professional classicist from the midByzantine period, a learned-man who lived by teaching and writing, on commission, several literary and commentary works recently called by Kaldellis (2007:301) "classics for dummies". Homer and his epics were of course in the centre of his interests, and to them he devoted the first part of his career ${ }^{2}$, namely by composing the Carmina Iliaca ${ }^{3}$ (c. 1133), a large Exegesis to the Iliad (c. 1140) and the Allegories to the Iliad and the Odyssey (the first one c. 1145, the last one some when after 1558).

One's effective dedication to Greek literature in the twelfth century (and to Homer in particular) needs no large explanation. Michael, Bishop of Ephesus early in the eleventh century, himself a learned commentator of Aristotle and pupil of Michael Psellos, testifies that boys used to learn Homer ${ }^{4}$ in schools at the length of thirty to fifty lines a day ${ }^{5}$; a few years before, the very Michael Psellos said he started to learn Homer at the age of eight, having finished the entire Iliad in just one year ${ }^{6}$. After having accompanied in Macedonia the eparch Isaac as secretary in a mission that was not to end up well, due to a love-polemic with his superior's wife, Tzetzes, in his early twenties, returned to Constantinople facing a deep problem, that of economical survival $^{7}$. He then decided (or had) to dedicate himself to teaching, and for that purpose, instead of writing yet another simple commentary on the Homeric poems, he preferred to rewrite them, in the same hexameter verse, besides commenting them by means of a huge corpus of scholia, the result of which were the Carmina Iliaca, his first erudite and Homeric task. He was by this providing his students ${ }^{8}$ with a comprehensive version of the entire Trojan saga, from Hecuba's dream into the main heroes' nostoi, altogether with his own thematic and (in some less frequent instances) linguistic explanations.

While the allegorical methods of Tzetzes in the Carmina - a poem that still nowadays longs for any vernacular translation - have been the subject of several studies, I am more interested in revising the issue of its sources. At this level - I shall argue - the place of the Peplos' epitaphs deserves a deeper consideration. Scholarship was able to identify the main sources used for the composition and commentary of the Car-

${ }^{2}$ On Tzetzes' Homeric interests and works see, among others, Browning (1975: 26-28), Morgan (1983), Budelmann (2002: 141-169), and Kaldellis (2007: 301-307).

${ }^{3}$ This is the title generally accepted since the poem's first publication by Schirach (1770). As for the manuscript tradition, a single codex (Leone's $\mathbf{O}$ ) seems to give a title to the work at the initial inscription:

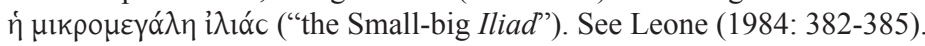

${ }^{4}$ On the general issue of Homer in Byzantium see Browning $(1975,1992)$ and Matzukis $(1992)$.

${ }^{5}$ See Heylbut (1892: 613, lines 4-7).

${ }^{6}$ See Sathas (1876: 14).

${ }^{7}$ For this biographical issue and its implications in the genesis of the poem see Braccini (20092010: 154-155; 2010: 88-89).

${ }^{8}$ Tzetzes mentions, in the scholium to the title of his work, to be "worried for what is useful to the

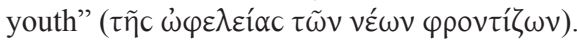

${ }^{9}$ Tzetzes' rewriting of the Trojan saga rests on three types of allegory, as explained in initial scholium — the psychological-aetiological method, the physical-astronomical, and the historical-pragmatic one. See Leone (1984), Braccini (2009-2010; 2011). 
mina Iliaca ${ }^{10}$ : Homeric scholia, tragic poetry (especially Euripides) and its scholia, Lycophron, Apolodorus, Philostratus' Heroicus, Quintus Smyrnaeus' Posthomerica, Tryphiodorus, Malalas and the Dictys Cretensis are only some of the most obvious. Therefore, when saying "my library is in my head; I own no books due to dire poverty" (all. Il. 15.87-88), in no way can these words, pronounced by Tzetzes, be taken literally. He actually made a large and deep use of written sources, confronted and commented them, in some cases not even choosing a version against another one, rather, as it was proper of erudite Byzantine scholarship ${ }^{11}$, presenting two or more versions for a same myth, both in the corpus of the poem or, more frequently, in the Scholia. Still, at some points there is a clear intention of originality, with aims for a mythurgical technique, i.e. the invention of mythic versions ${ }^{12}$, more generally in the realms of allegory. As for the Peplos' epitaphs inserted in the Scholia, Tzetzes' use of them as a source seems to be rather different from the Byzantine practice, assuming a role of illustration more than confirmation. They are, nonetheless, yet another expression of erudition (and a meticulous one, I must say).

I shall now investigate Tzetzes' acquaintance of these epitaphs, an issue that shall lead us through the treatise's knowledge and transmission during the Byzantine period. The Peplos, credited as Aristotelian right after the philosopher's death ${ }^{13}$, is nowadays generally believed to be apocryphal. It is actually mentioned among the main (and oldest) list of Aristotelian works inserted at the end of the Vita Hesychii, also called Menagiana thanks to its first edition, by Menagius, in 1663. In spite of its uncertain author, scholars have come to think that the Menagiana, as its counterpart Vita Laertiana, both depend on a common source from the third century BC, i.e., that both might reproduce an inventory of the works credited as Aristotelian held at the very library of the Lyceum, only a few decades after the philosopher's death. In another words, even if Aristotle did not write the Peplos, one of his best students might have done so, already during the philosopher's lifetime or not much later. Nonetheless, any investigation on this work must start by looking at the testimony of Eustathius (in Hom. Il. $2.557=1.439$ van der Valk $=$ test. $\mathbf{6}^{14}$ ):

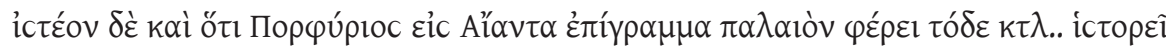

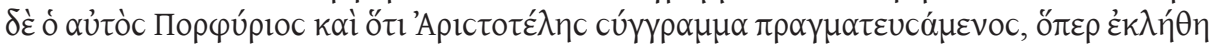

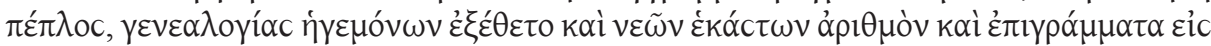

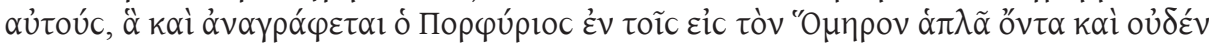

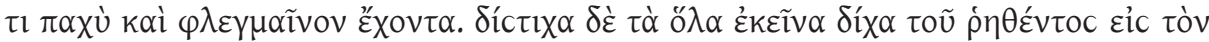

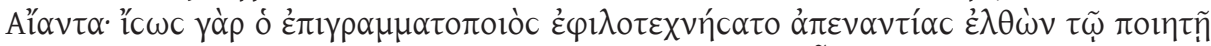

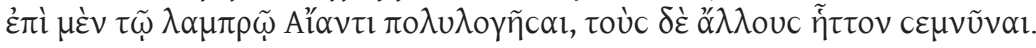

${ }^{10}$ See especially Leone (1984: 405), Braccini (2009-2010: 156-157; 2010: 88, 91-92).

${ }^{11}$ Cf. Leone (1984: 387), Braccini (2009-2010: 157-159).

${ }^{12}$ Braccini (2009-2010: 164-169). One particular case is the rewriting of the astronomical phenomena from the opening of Iliad 24 (hom. 2.275-290), on which the scholium clearly states, "all of this is my

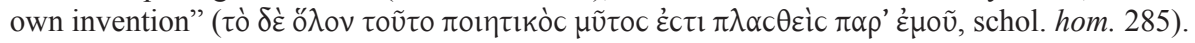

${ }^{13}$ For the argument, see Moraux (1951: 237-247), and Martins de Jesus (2015: 1-2).

${ }^{14}$ In bold I indicate the number of the testimonia (test.) and epitaphs (text number) as printed in my edition (Martins de Jesus 2015). 
In the same twelfth century we are focussing on, Eustathius mentions a collection of brief epitaphs of Homeric heroes collected by Porphyry ( $3^{\text {rd }}$ century AD) from a work supposedly by Aristotle entitled Peplos, saying the work established "the genealogies of leaders [and] the number of ships each one of them had". Only afterwards does

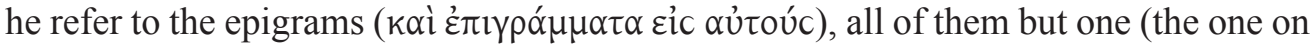
Ajax $=$ number 7$)^{15}$ elegiac couplets. When considering all the few testimonies available, as well as a group of similar works from Greek historiography ${ }^{16}$, from the early fifth century BC onwards, one must see the original Peplos as a work of mythology and historiography, including poetic epitaphs most probably at the end of the story of each character, when describing his death, burial and even divinization, in the context of the cultic institution surrounding his burial place. As for its date of composition (or better, organization), Gutzwiller (2010) provided a phraseological and linguistic analysis of some epitaphs in relation to several pre-Hellenistic sources (poetry, epigraphy, and even ceramics) that supports the existence of a fifth and fourth century $\mathrm{BC}$ oral and written tradition of the majority of epigrams related to the Peplos. Being so, one can no longer assume a Hellenistic or even Imperial date for the origin of the epitaphs, as believed by several scholars ${ }^{17}$.

In 1566 Henri Estienne published a first collection of 48 epitaphs in appendix to his edition of the Planudea, copied from a thirteenth century Laurentianus manuscript (henceforward La $)^{18}$. That was the corpus known and republished until 1798, when

${ }^{15}$ In the Greek Anthology (AP 7.145), the same epigram is ascribed to Asclepiades (29 HE), with a single variation in the last verb, so it must depend on a Planudean source. Asclepiades' version must have been included in the garland at some point, replacing a lost couplet that could have formed part of the Peplos. Yet an epigram composed within the same pattern was transmitted and ascribed to Mnasalces (17 HE) by Athenaeus (5.163), in the form of an ecphrastic epigram on some unknown statues of Virtue

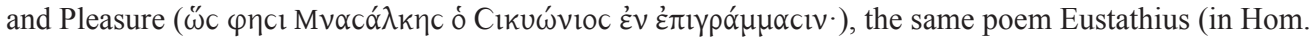
Il. $2.557=1.439$ van der Valk = test. 6) considered a parody of the authentic Ajax epigram. See Gow-Page (1965, vol. II: 137), Cameron (1993: 391-392), Gutzwiller (2010: 247-249), and Martins de Jesus (2015: 7-9).

${ }^{16}$ E.g. Damastes' On the progenitors and ancestors of those who fought at Troy and On poets and sages (Suda $\Delta 41=$ FGrH 5 T1), and Polus of Acragas' (a character in Plato's Gorgias) Genealogy of those, both among Greeks and barbarians, who fought at Troy, and how each one of them died (Suda п2170 = FGrH 7 T1. For these parallels, see Cameron (2004: 388-389) and Gutzwiller (2010: 224-225).

${ }^{17}$ Schneidwin (1846: 1-3) strongly believed that the treatise was the work of Aristotle and that the epigrams were part of its first version, suggesting that the Peplos was a guide of heroic behaviour for the young Alexander. With regards to the discussion of the epigrams' authorship, Rose (1863) was of the opinion that they were the work of a Hellenistic author, who might have both composed and collected epitaphs from inscriptions. Wendling (1891), also in favour of a Hellenistic author, considered them to be composed around 250-150 BC as additions to the original treatise, which would be known to Porphyry's generation via Theophrastus' edition of the Aristotelian corpus. In what marked the critical re-approach to the Peplos, Cameron (1993) refuted Aristotle's authorship for both the treatise and the epigrams, and considered some of these to be the product of a period no earlier than the end of the second century and no later than $60 \mathrm{BC}$, an opinion close to Bergk's (1882: 343-344).

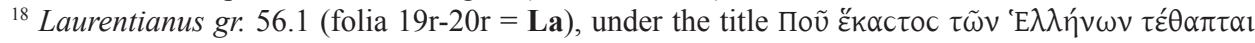

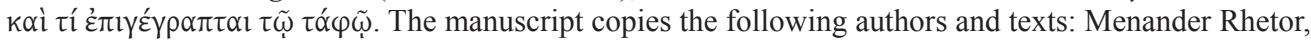
the so-called Paradoxographus Florentinus (where the epitaphs come from), mythographic excerpts, the Certamen Homeri et Hesiodi, four orations of Theophylact of Bulgaria, the Declamations of Polemo, excerpts from Gregory of Corinth, Pollux's Onomasticon and Polyaenus' Strategemata (apud Cameron 
Burgess added the garland with fifteen components extracted from the late fifteenthcentury London. Harleianus gr. 5662, a codex that contained both Tzetzes' Carmina and Scholia. Burgess noted that Tzetzes also copied, with minor variations, fourteen epitaphs that could already be read in La, besides composing yet another eight for the heroes he believed worthy of it and for whom he was not able to sort an extant component. These are the ones I call apochrypha Tzetziana, and on them shall this paper focus ahead.

But, at what level did Tzetzes know these epitaphs and which could have been his sources? Eustathius, as seen before (test. 6), mentions Porphyry as his source, particularly the inclusion of the epitaphs in his commentaries on Homer (

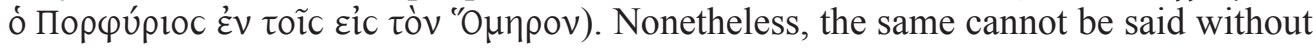
further discretion in relation to Tzetzes. By contrary, one must assume the existence of several manuscript garlands from the fourth (even late third) century AD onwards and available during the entire Byzantine period, probably derived from Porphyry's recollection, which gathered those epitaphs once extracted from the Peplos alongside with others that fit their structure (elegiac couplets) and subject (Homeric heroes, poets and other wise men from Antiquity). In another words, it must be assumed an independent circulation for these epigrammatic components, which I summarise under the sign $\boldsymbol{\alpha}$ in the stemma I reproduce in picture 1 (= Martins de Jesus 2015: 30), where I offer a first comprehensive scheme for the transmission of the epitaphs from Aristotle's time into their copy in the twelfth and thirteen centuries.

While not mentioning the Peplos directly in the Scholia, the truth is that Tzetzes claimed to be familiar with it on other occasions ${ }^{19}$, and I came to believe that its men-

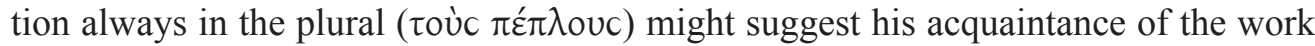
already in the form of epigrammatic garlands, rather than the treatise itself ${ }^{20}$ or even Porphyry's recollection, as it was the case for his contemporary Eustathius.

\section{TEXTUAL TRANSMISSION AND THE ANTHOLOGIES OF M AND MD}

Textual collation proved long time ago that Tzetzes and the anonymous scribe of La made use of different manuscript sources. Among other aspects, two arguments come to sustain this evidence. First, when justifying the composition of an epitaph for Antilochus (schol. posthom. 477 = number 92), Tzetzes mentions to have been unable

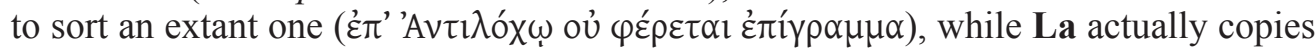

2004: 335-339). Different possibilities were given regarding the date of the codex, since it portrays different hands (and different kinds of paper) and was probably written at different times, as shown by Cameron (2004: 336-337). The paper could indeed be linked back to any date within the second half of the eleventh century and the end of the fourteenth, while the codex may be considered a bombycin, produced using an Arabic paper that was very common at the time. While earlier editors thought it to be as late as the fourteenth century, Rose $\left({ }^{3} 1886\right.$ : 568$)$ considered it from the end of the thirteenth century, and this is the generally accepted opinion.

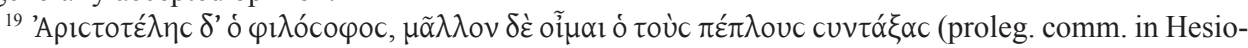

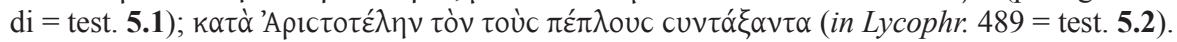

${ }^{20}$ This possibility was suggested by Braccini (2009-2010: 156) 
an epigram on that hero (number 11). Furthermore, Tzetzes states the acquaintance of (and copies) two epitaphs in the case of two heroes, while the codex sorts a single component for each one - namely, on Tlepolemus (schol. hom. 91a = number 55) and Hector (schol. hom. 489 = number 60). One might suggest that La performed a selection of 48 components from a much larger manuscript anthology (one that Tzetzes knew entirely), if it was not for the fact that also that codex copies, in more than one case, two epitaphs for a single hero. Much more plausible would be that its scribe used a reduced anthological source, where a selection of epitaphs had already been made, with some cases of duplication only allowed for the most important heroes ${ }^{21}$; and that Tzetzes, working with a larger collection or (I believe) several ones, wanted to be as inclusive as possible, as it was proper of the kind of Byzantine erudition he affiliates to.

Table 1 presents all the epitaphs quoted by Tzetzes in his Scholia, namely the ones he shares with the Laurentian tradition (numbers 1-14), the ones known only from him (numbers 15-29) and, finally, the apochrypha Tzetziana (numbers 30-37). In Column 2 I state my own numeration of the epitaphs (Martins de Jesus 2015), followed by Rose's ( ${ }^{3} 1886$, repr. 1967), the position of the components in Tzetzes' Scholia, the heroes' names, and finally, in the last two columns, their position in two late-fifteenth century codices held at the National Library of Spain (M = Matrit. gr. $4562 \mathrm{ff} .127 \mathrm{~V}-$ 128r [picture 2]; Md = Matrit. gr. 4621 ff. 128r-128v) 22, copied by Constantine Lascaris, which I was able to directly collate and for the first time include in an edition of these components. While $\mathbf{M}$ is a more meticulous codex than $\mathbf{M d}$ - which at several times gives the impression of being something like a personal notebook of Greek literature - both must have been written in the last years of the fifteenth century, most probably in Messina, where the scribe is said to have lived since $1466^{23}$.

Between the mentioned folia of both codices, alongside with a few epitaphs copied outside them, Lascaris sorts a total of 33 out of 37 epitaphs copied by Tzetzes, including some of the apochrypha (about $86,5 \%$ of the Tzetzian selection). Textual collation proved that Lascaris must have used more than one codex for the copy of the epitaphs in $\mathbf{M}$ and $\mathbf{M d}$. On the other hand, several material and textual evidences point to their copy first in Md - which would be something like a notebook of Greek literature - and later in $\mathbf{M}$, where the scholar essayed some corrections, even if not always the best ones ${ }^{24}$. More generally, these folia are the only two extant examples of anthological copy of these poetic components besides La, which, as said before, is part of a different (non Tzetzian) path of transmission. Less than fifty years after the fall of Constantinople, Lascaris' interest in these epigrams, of which he put together two small garlands from the Tzetzian manuscripts he possessed or had access to, is still to be seen as an ultimate testimony of this corpus' accuracy and importance for Byzantine scholars and learned-men.

${ }^{21}$ Numbers $\mathbf{1}$ and $\mathbf{2}$ (Agamemnon), $\mathbf{4}$ and $\mathbf{5}$ (Achilles), $\mathbf{9}$ and $\mathbf{1 0}$ (Nestor), and $\mathbf{1 2}$ and $\mathbf{1 3}$ (Odysseus), in the case of La.

${ }^{22}$ For a detailed examination of $\mathbf{M}$ and Md see Andrés (1987: 33-36, 136-140), and, concerning the folia where the epitaphs are copied, Martins de Jesus (2015: 14-16).

${ }^{23}$ On the life and Works of Constantine Lascaris see Martínez Manzano (1994: 7 ff.; 1998: 3-20).

${ }^{24}$ For the collation of $\mathbf{M}$ and Md with the remaining Tzetzian manuscripts see Leone (1985) and Martins de Jesus (2015: 14-19). 


\section{TZETZES' APOCHRYPHA: A COMPROMISED REWRITING OF HOMER}

The epitaphs Tzetzes collects from his manuscripts sources are inserted in the Scholia with erudite purposes of gathering the most information possible, either saying

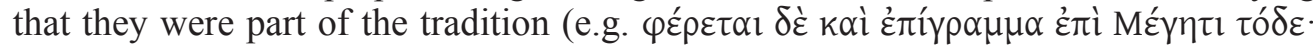

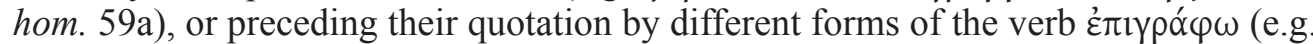

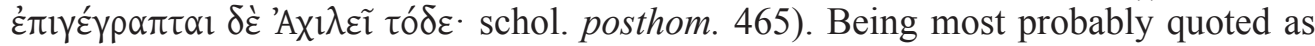
found in the available manuscript sources, one could not look for connections (no other than accidental) between a hero's description in the Carmina and the epitaph on him. They too are, as the entire corpus of Scholia, "further information" for students of Homer, and that is why they look forward to be the most complete and comprehensive as possible. Once again, the words and epitaphs on Tlepolemus and Hector can function as examples, as they mention two traditional burial and cult places for both heroes - namely Troy and Rhodes, for the first, and Troy and Thebes, for the last one.

From another perspective, the very inclusion of these epitaphs in the scholia might be a reflection of the very Byzantine addiction for focussing on a character's physical and psychological description, the rhetorical device known as zikovíc $\mu o^{25}$. A frequent device at least since the third century AD, with Philostratus - an important source for Tzetzes and every Byzantine scholar interest in Homer and his characters - they were also part of nowadays lost works such as the Dictys Cretensis, which the Byzantines should know in its full Greek version" ${ }^{26}$, called by Dragon (2005: 197) a "Hollywoodean peplum". Closer to Tzetzes' time is Isaac Komnenos (called "Porphyrogenetes"), who composed three philosophical treatises based on Proclus and two commentary works on Homer, an author usually identified with the third son of Emperor Alexios I Komnenos (ruler between 1081-1118) and Empress Irene Doukaina (16 January

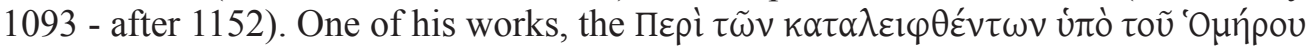
(Hinck 1873: 58-88), presents after the commentary of the poems a list of eikonismoi for the main Homeric heroes. In more than one case the similarities with Tzetzes' lines of the Carmina - where some heroes also receive such kind of description - are startling, as well as their influence on the composition of the epitaphs ${ }^{27}$.

From now on, I shall focus on the epitaphs composed by Tzetzes as apochrypha to the tradition of the Peplos (numbers 30-37 in Table $\mathbf{1}=$ numbers 86-93 of my edition), where the author's literary interests are more clearly identified. By putting them side to side with other Byzantine texts, I intent to demonstrate how Tzetzes made use of both contemporary and ancient sources to create a small group of elegiac couplets truthful to Homeric diction but also pregnant of a personal (and yet very Byzantine)

${ }^{25}$ On them, see Dragon (2007: 124-135).

${ }^{26}$ It was a romance description of the events of the Trojan War, enunciated by Dictys from Knossos, supposedly a companion of Idomeneus, of which we only possess a Latin abbreviated version: Dictys Cretensis Ephemeridos Belli Troiani libri, a Lucio Septimio ex Graeco in Latinum sermonem translate. Ed. W. Eisenhut, Lipsiae, ${ }^{3}$ 1994. See Dragon (2005: 197 e n. 8).

${ }^{27}$ Very similar, for instance, are Tzetzes and Isaac's description of Trolius (posthom. 382-384; Isaac Porph. p. 85, 21-23 Hinck) or Polyxena (posthom. 498-508; Isaac Porph. p. 87, 1-8 Hinck), two examples this paper shall analyse. Nonetheless, there is no need to sustain the direct use of one by another; both could have used a same source, as it might be the case of the Dictys Cretensis. 
meaning. Tzetzes is clear when stating that no epigram from the tradition could be

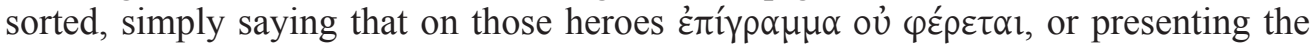
epitaphs as his own and, in some cases, using the imperative forms of the verb cilui to

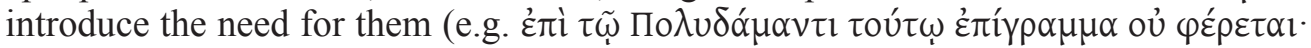

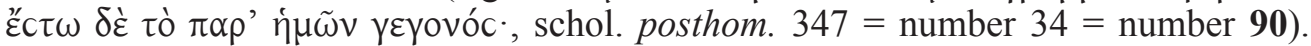
The eight heroes he writes an epitaph for (Hiera, Palamedes, Euphorbus, Thersites, Polydamas, Trolius, Antilochus, and Polyxena), some of them minor characters of the Homeric tradition, received nevertheless a huge attention in late-Antique epics, as well as other literary genres, from the Classical, Hellenistic and Byzantine periods, all of them part of Tzetzes and any Byzantine scholar's library.

The first two striking examples of the author's use of his sources and personal interpretation of myths are those of Hiera (number $30=$ number 86) and Palamedes (number $31=$ number 87). Hiera, Telephus's wife ${ }^{28}$ and the queen of Mysia killed by Nireus (antehom. 278), is presented in the Antehomerica fighting at the head of the

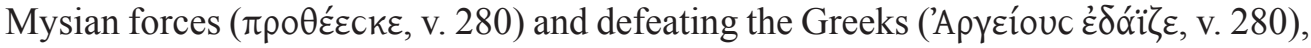
mad because of Achilles' rage against her husband. This is how Tzetzes comments on her in the Scholia (schol. antehom. 278a +284 ):

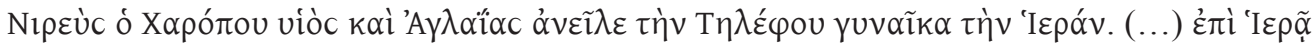

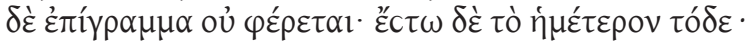

Múciov à $\mu \pi \varepsilon \delta i ́ o v \underline{\kappa \alpha \lambda \tilde{\eta} c ~ \varepsilon ̇ \varphi u ́ r \varepsilon \rho \theta \varepsilon ~ K o \lambda \omega ́ v \eta c ~}$

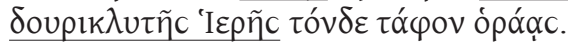

\section{$(\mathbf{H G}=\mathbf{z F}=) \mathbf{h M M d O}$}

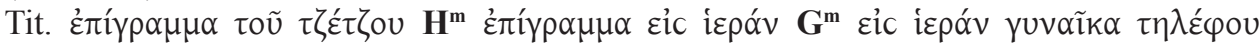

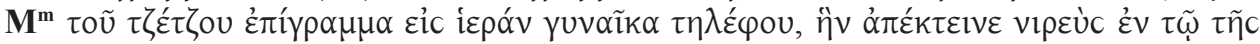

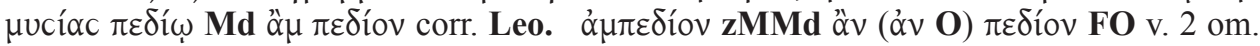

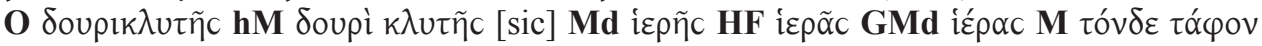

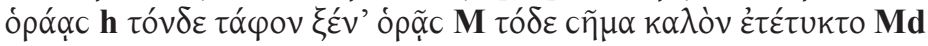

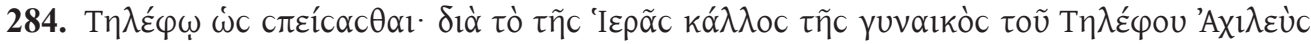

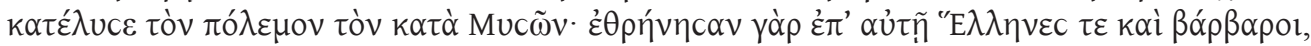

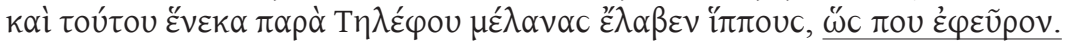

While praising the woman's beauty - she who was even more beautiful than Helen herself (v. 286) - Tzetzes states that it was the grief caused by her death, shared by Mysians and Greeks, the reason for the truce and the departure of the Greek army (antehom. 283-284 + schol. antehom. 284). As for his source, he only mentions to have found the story in an unidentified author ( $\ddot{c}$ rov $\dot{\varepsilon} \varphi \varepsilon \tilde{u} \rho \circ v$ ). While it seems obvious that Philostratus' Heroicus (chap. 23) was his model for almost every aspect of the myth,

${ }^{28}$ Different traditions ascribe different wives to Telephus. According to Diodorus (4.33), the Mysian hero was married to Argiope, the daughter of Teuthras, after it was discovered that Auge was his mother. Philostratus (Her. 23), however, makes Hiera his wife, killed in battle by Nireus, the same version depicted on the Pergamon Altar. 
the decision of the truce caused by the grief for Hiera's death is not found elsewhere, so that it has been considered an example of Tzetzes' mythic invention (or, as Braccini 2010 puts it, feminine mythurgy). For what matters, the epitaph for Hiera highlights the two main features of the myth, namely her courage (similar to a man's) and beauty: while the last one is metonymical transferred into the Mysian ground that keeps her

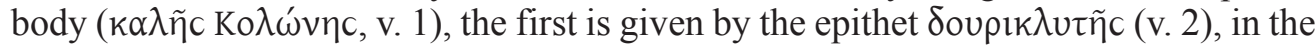
Homeric Poems only applied to masculine heroes ${ }^{29}$.

While some scholars saw in the Tzetzian Hiera a reflection of the scholar's private story, the one involving Isaac's wife, which ultimately forced his own return to Contantinople ${ }^{30}$, I believe she must be seen in the wider context of the women's position in Byzantium. Allotted with an inferior status by confessional ideas and literature ${ }^{31}$, women also knew an overwhelming political influence that soon made them part of the governmental elite ${ }^{32}$. Tzetzes himself received, around 1145, the Empress Irene's well-pay commission for writing a commentary on the Iliad, needing as she was for an Introduction to Homer. Proving that the female character had a huge political meaning for Tzetzes is the fact that, in that work (the Allegories of the Iliad), Hiera's courage and beauty are once again the subject of several lines (proem. 1005-1024), in a formulation as close to the Antehomerica as the metrics of the so-called political verse allows it.

Palamedes ${ }^{33}$, as far as Tzetzes is concerned, is a victim of ingratitude. The truth is Odysseus never forgave him having to ship to war. Later, when Palamedes advised the Greeks to return home, Odysseus hid gold in his tent and wrote a fake letter purportedly from Priam. The letter was found and the Greeks accused him of being a traitor, and therefore Odysseus and Diomedes stoned him to death (Philostr. Her. 33; Tzetz. antehom. 380-385) ${ }^{34}$. This is how Tzetzes celebrates that hero, one of tremendous meaning for him (schol. antehom. $406 \mathrm{~b}=$ number 87):

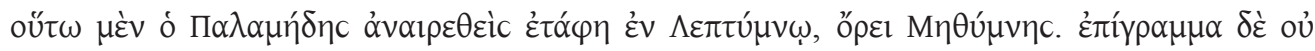

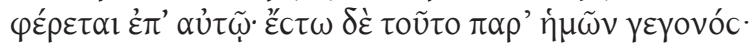

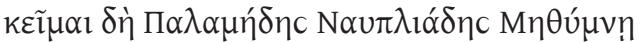

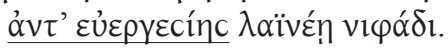

$(\mathrm{HG}=\mathrm{zF}=) \mathbf{h M}$

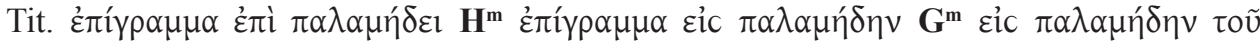

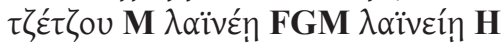

${ }^{29}$ E.g. Il. 21.233 (Achilles), 11.396, 16.226 (Odysseus), 5.45, 13.467, 476 (Idomeneus), 16.472 (Automedon), 16.619 (Meriones), Od. 15.544, 17.71 (Peiroos).

${ }^{30}$ See Braccini (2010: 100-102).

${ }^{31}$ See Maltese (2006: 25 ff., 105 ff., 129 ff., 173 ff.).

${ }^{32}$ See Ronckey (2002: 112-114).

${ }^{33}$ About Tzetzes' on Palamedes see Leone (1984: 388), and Braccini (2009-2010: 167-168; 2010 : $94 \mathrm{ff}$.).

${ }^{34}$ According to other accounts, the two warriors drowned him during a fishing expedition (Paus. 10.31.2, citing the Cypria). 
Although a major character in some accounts of the Trojan War, Palamedes is not mentioned in the Iliad $^{35}$. Chapter 33 of Philostratus' Heroicus is entirely dedicated to him, a text that must have been in every Byzantine scholar's head (and library). It includes already the hero's eikonismos (Her. 33.39-40), a pattern later found twice in Tzetzes (antehom. 397-404; Hist. 3.172-184) and once in Isaac Porphyrogenetes (p. 82, lines 9-12 Hinck). Tzetzes highlights the hero's innocence and resignation in face of injustice, quoting what should have become a proverbial line ( $\chi \alpha \tilde{i} \rho \varepsilon,{ }^{\prime} A \lambda \eta \dot{n} \theta \varepsilon 1 \alpha$

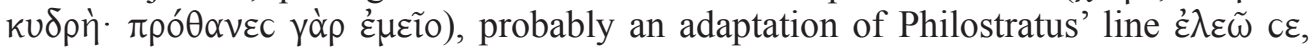

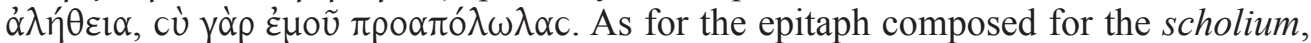

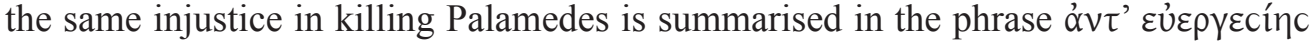
("against my good-service"), where one can read many referents, from the hero's participation in the several embassies previous to the War until the many scientific achievements attributed to him by late-Antique authors.

While a relation between the treatment of Hiera and Tzetzes' private life seemed an overstatement to me, the same cannot be said in the case of Palamedes. Tzetzes himself insists in that connection, both physical and temperamental, in the Histories

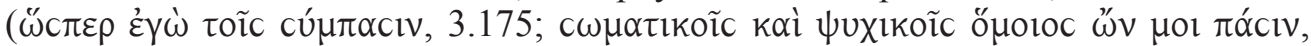
3.181), so that it might have been a personal affection of his. Even more striking is the hero's description in the Allegories of the Iliad (proem. 724-734), alongside with

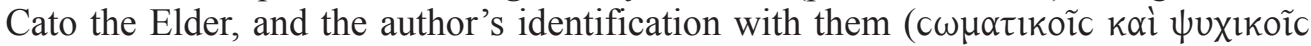

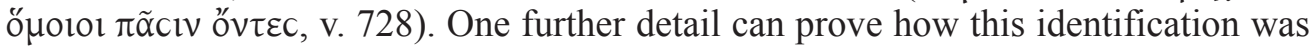
actually a personal goal. If we are to accept that Isaac's eikonismoi somehow held the heroes' description as accepted in mid-Byzantium - and Tzetzes himself follows this pattern in more than one occasion - the change of the colour of the hair from black

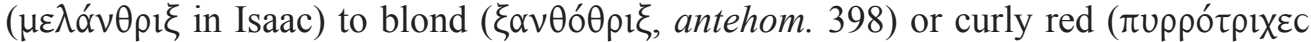
all. Il. proem. 727) could actually be a means to more directly relate the hero with himself.

The next hero to be celebrated is Euphorbus (hom. 223a = number 88), an important case study in relation to the sources of the Carmina Iliaca:

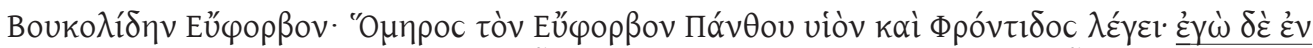

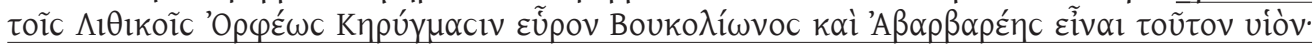

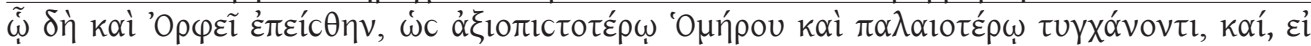

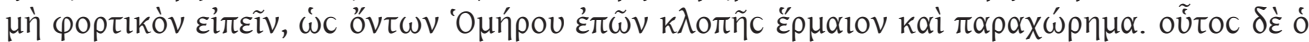

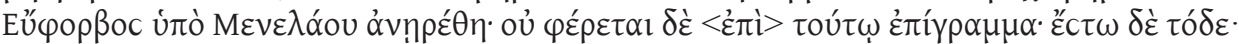

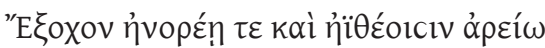

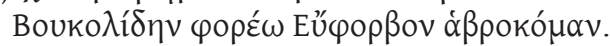

\section{$(\mathrm{HG}=) \mathbf{z M M d O}$}

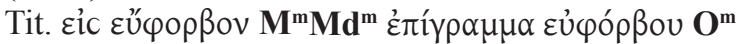

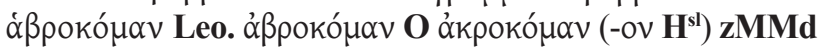

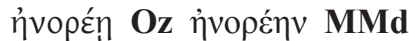

${ }^{35}$ Something already uncomfortable to Philostratus, who, in the Life of Apollonius (3.22) states that "Palamedes found his bitterest enemies in Odysseus and Homer; for the one laid an ambush against him of people by whom he was stoned to death, while the other denied him any place in his Epic." 
Tzetzes' source is clearly identified in the lines of the scholium (cf. Orph. Lith.

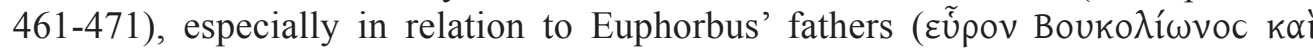

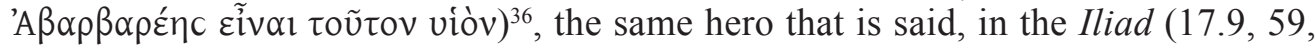
81 ), son of Panthous (and not Boukolos ${ }^{37}$ ), and the first man to wound Patroclus (16.806-809). Yet another proof of the Orphic influence is to be seen in the epithet restored by Leo. as $\alpha \beta \beta o \kappa o ́ \mu \alpha v$, which, mistakenly copied by all manuscripts (also $\mathbf{M}$ and Md) ${ }^{38}$, is found among the Orphica collection ( $\dot{\beta} \beta$ pokó $\mu \eta$ Orph.H. 56.2) ${ }^{39}$. That the manuscript consensus is wrong can also be demonstrated by Tzetzes' own description of the hero later in the Histories (1.229-230), where a similar compound is used:

Eü

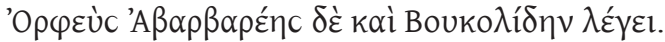

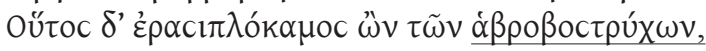

For everything else, Tzetzes follows the Hellenistic and Byzantine poetic tradition surrounding Euphorbus, who, especially after Philostratus' Heroicus (chap. 42), became an example of beauty among the Trojans, for his youth and mainly for his (blond)

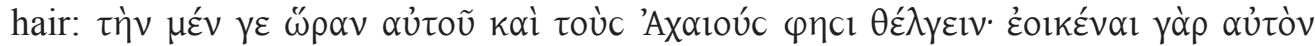

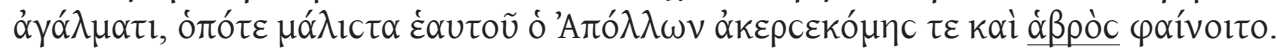

Thersites (schol. posthom. $207=$ number 89), known from Homeric tradition as the ugliest and most coward of the Greeks, the man Achilles killed for joking about

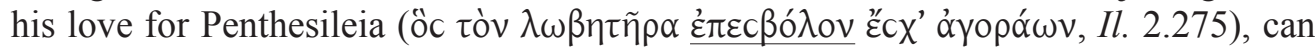
somehow be seen as an anti-hero, who nonetheless deserves the honour of an epitaph on him:

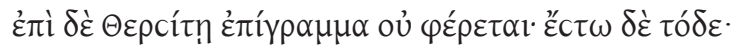

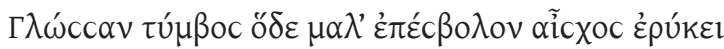

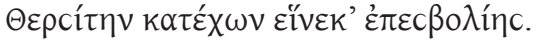

\section{HMMdO}

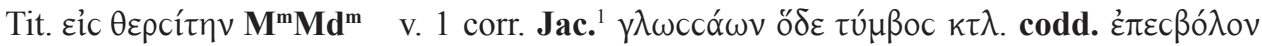

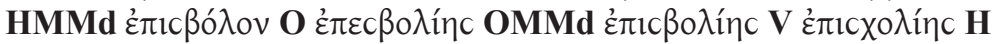

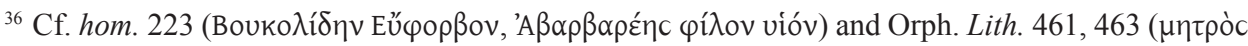

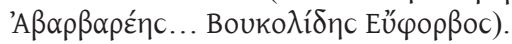

${ }^{37}$ In the Iliad (15.337-338), the son of Boukolos is Sphelus, the commander of the Athenians in the Trojan War who was slain by Aeneas.

${ }^{38}$ The scribe of $\mathbf{O}$, in the sixteenth century, corrected already the epithet, yet failing in the initial

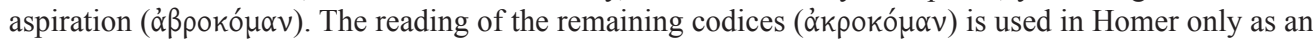

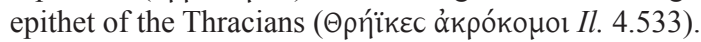

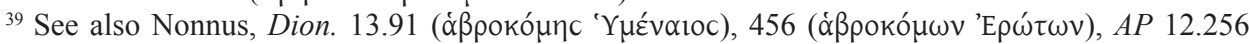

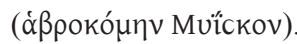


The hero must have become an important character in late-epics and novel, as proved by Quintus Smyrnaeus' Posthomerica (1.984 ff.), where the very same episode (that of Thersites mocking with Achilles' love for the Amazon) gets a large development. Tzetzes' epitaph is very close to Homeric diction, especially due to the anaphor

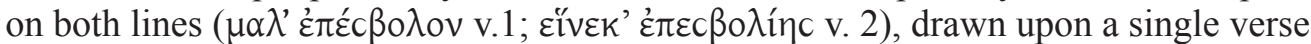

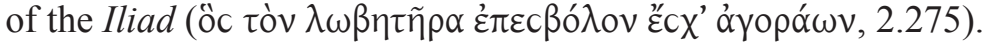

It follows Polydamas (school. posthom. $347=$ number 90), another Trojan and the brother of Euphorbus. Homer gives no foreshadowing of his death, nor is he mentioned in any of the later poems dealing with the aftermath of the war, so that it must be assumed that he perished in a general slaughter after the fall of Troy:

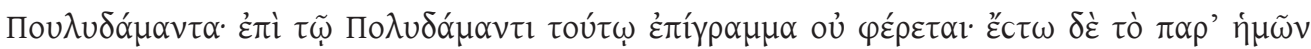
үeүovóc.

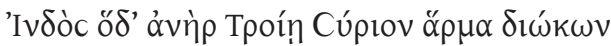

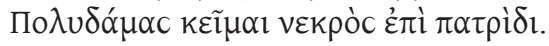

\section{HMMdO}

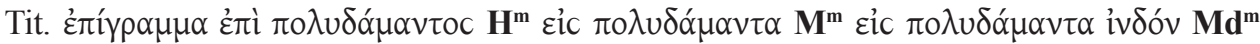

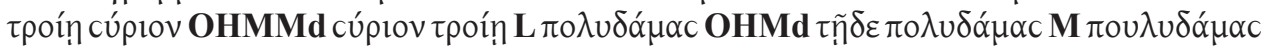
$\mathbf{V} \kappa \varepsilon \tilde{\imath} \mu \alpha \mathbf{l}$ OMMd $\kappa \varepsilon \tilde{\tau} \tau \alpha_{l} \mathbf{H}$

Tzetzes must be referring to $\mathrm{Il}$. 13.721-753, the moment when Polydamas wisely advises Hector to retreat and restrain his chariot, so that the attack can be better planed (see esp. 13.749). Therefore, his interest on this hero must be due to his role of goodadviser, almost in direct opposition to Thersites' shameful words.

Troilus and Antilochus (numbers 91-92), yet two other Trojan heroes, are also examples of Tzetzes' affiliation with Byzantine interpretation and rewriting of the Homeric saga by means of the above-mentioned rhetorical device of the eikovícuol. In the posthomerica, after announcing the description of the Trojan kings (v. 361), Troilus' eikonismos is the last one Tzetzes provides (vv. 382-384):

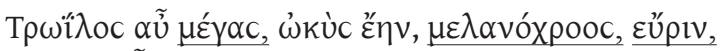

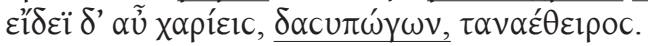

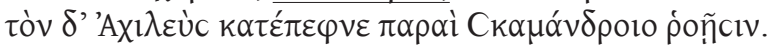

The formulation is very close to that of Isaac Porphyrogenetes, when saying that

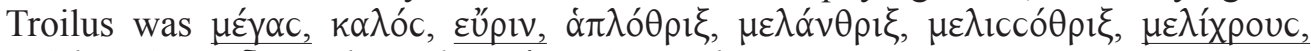

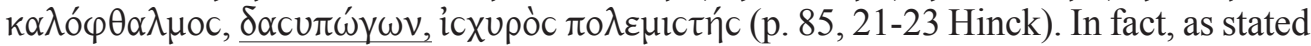
before, Isaac's eikovícuol are somehow to be seen as the pattern for these heroes' description in Byzantine literature, and textual resemblances point in the way of a direct knowledge of Isaac's text by Tzetzes. As for the apochryphum on Troilus (schol. posthom. $385 \mathrm{~b}=$ number 91 ), none of these physical attributes is detected. Instead, Tzetzes must have built a traditional elegiac couplet, modelled from the extant epitaphs he knew: 


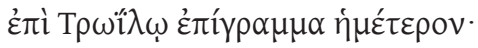

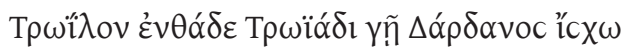

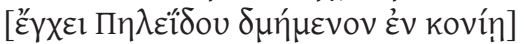

\section{HMdO}

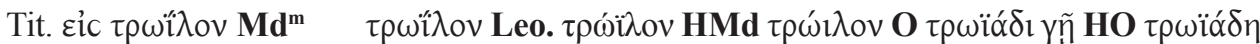

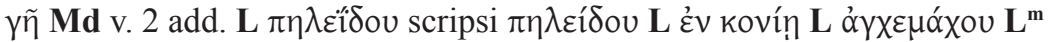

The pentameter of the couplet lacks in any Tzetzian manuscript that transmits this scholium (namely $\mathbf{H}$ and $\mathbf{O}$ ), therefore also in $\mathbf{M d}$, the only one of the two Lascarian codices copying the epitaph. As printed here and in any edition of Tzetzes' Scholia, it is a reconstruction only found in $\mathbf{L}$ (Regius gr. $16 \mathrm{C}$. IV), a codex dated not prior to the second half of the sixteenth century. While no actual information on the version originally followed by Tzetzes is given, when commenting Lycophron's Alexandra (in Lycophr. 307) he talks about Troilus seeking to avoid the unwanted sexual advances of Achilles by taking refuge in the Temple of Apollo Timbraeus and, when he refuses to come out ${ }^{40}$, how the son of Peleus killed him on the altar. One must therefore believe that the same version was followed in the epitaph, even if it is not clear whether that

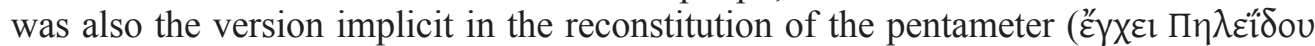
$\delta \mu \eta$ frvov) by the scribe of $\mathbf{L}$, where no mention to Achilles' passion is found. Different must have been the version of the lost Greek epitaph at some point transmitted among the Greek components ascribed to the Peplos. On it, some information is nevertheless given by Ausonius ${ }^{41}$ who, back in the fourth century AD, when translating into Latin the Pepli Epitaphia, might be aware of it (most probably from Porphyry's recollection of the epitaphs $\left.{ }^{42}\right)$, and actually included a quatrain on that hero $(8$ Green $=$ number 78$)$ :

Hectore prostato nec dis nec viribus aequis

congressus †ंsaevo $\dagger$ Troilus Aeacidae,

raptatus bigis fratris coniungor honori,

cuius ob exemplum nec mihi poena gravis.

${ }^{40}$ In a speculative reading, the verb íc $x \omega$ of the hexameter (being the subject of enunciation the tombstone) could somehow suggest Troilus hiding from Achilles.

${ }^{41}$ Ausonius' epitaphs were first published in Venice in 1472, and later in Milan, in 1490. Therefore, it is highly possible that the scribe of $\mathbf{L}$ knew one of these editions and proceeded to essay a reconstruction of the lost pentameter.

${ }^{42}$ Ausonius only mentions to have collected the epitaphs "apud philologum quondam", but textual evidences and the very implicit title of the work ("Epitaphia... sepulcrales heroum, qui bello Troico interfuerunt") made scholars assume that Porphyry was his source a long time ago. Nevertheless, as recently pointed out by Morelli (2013: 77), he could have used other written sources, other works on ancient mythology, cult or geography. Having found the poems in one or several works of prose, Ausonius thus proceeds to reorganise them in a sylloge, in a new poetic libellus based on the poetic adaptation of Greek originals into Latin elegiac metre. This is most frequently done by enlarging the original Greek couplets, following a method of thematic and formal "duplication" of his model. On the method of Ausonius when working with the Greek originals see Di Giovine (1998, 1999, 2000) and Morelli (2013). 


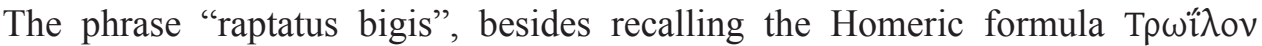

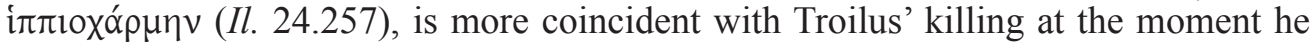
was unharnessing or exercising his horses, as told in Eustathius (in Il. $24.251=4,897$ van der Valk). While no reference to the homoerotic affair can be traced in Ausonius' version, it seems plausible that the oldest version of the epitaph was actually more Homeric, i.e. that it associated the hero with the chariot-rider office, what would have also allowed him to relate with the better-know fate of Hector, dragged in the Trojan dust by Achilles' horses.

Also on Antilochus, the son of Nestor whose ashes where enshrined in a mound on the promontory of Sigeion, alongside with those of Achilles and Patroclus (Il. 23.83 ff., 23.125-126; Od. 24.74-84) ${ }^{43}$, Tzetzes writes an epitaph (schol. posthom. $477=$ number 92):

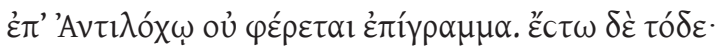

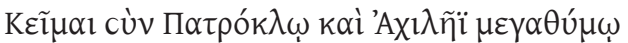

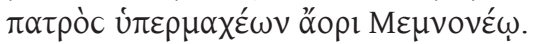

\section{OH}

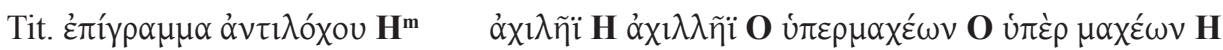

While it seems certain that number 11 (the extant epitaph on Antilochus, the same

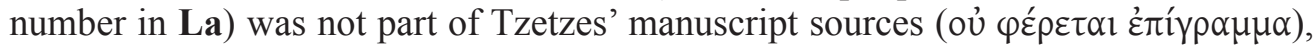
the apochryphum on that hero is nonetheless very close to the extant one. The fact is that Antilochus was a hero frequent among late epics and commentaries, and Tzetzes himself recognizes knowing the tradition of his afterlife destiny with Achiles and Patroclus: if in the Posthomerica one can only read the hero's Eikovícuoc (477-480), very similar to the one found in Philostratus' Heroicus (26), a few lines before he

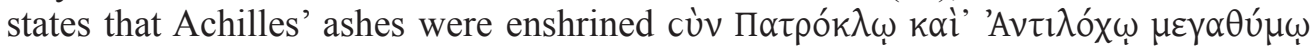

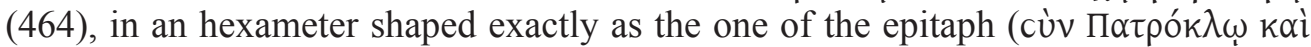

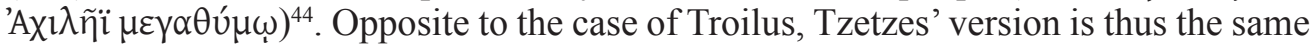
one found in the extant (and therefore older) epitaph he claims to be unaware of, reinforcing both of them the need to glorify Antilochus for his courage on saving his father

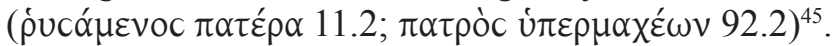

The last of Tzetzes' apochrypha is on Polyxena, the Trojan princess allotted to Achilles and sacrificed at that hero's tomb (schol. posthom. 508b = number 93):

${ }^{43}$ Yet in the Odyssey (11.467-468), the three heroes are represented as united in the underworld, walking together in the Asphodel Meadows. According to Pausanias (3.19.13), they dwell together in the island of Leuke.

${ }^{44}$ The acquaintance of this information is repeated in the commentaries on Lycophron's Alexandra (in Lycophr. 273).

${ }^{45}$ According to Pindar (Nem. 6.28), Antilochus sacrificed himself to save his father Nestor at the moment he was attacked by Memnon. That is also the version of Ausonius ep. 7, the adaptation of number 11, where it is also mentioned Antilochus' pietas to his father (praemia virtutis simul et pietatis adeptus, / servato Anthilochus Nestore patre obii, vv. 3-4). On Ausonius' epitaph see Di Giovine (2000). 


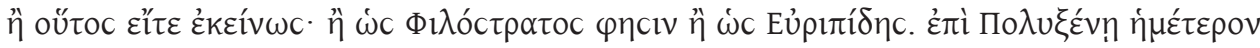

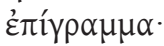

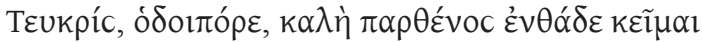

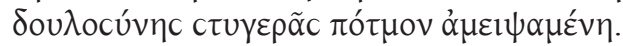

\section{HLVO}

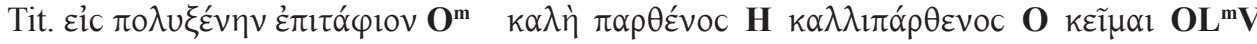
$-\tau \alpha \mathbf{l} \mathbf{H}$

The scholium identifies the main sources for this myth, namely Philostratus' $\mathrm{He}$ roicus and Euripides, with no mention of a concrete tragedy, even if Hecabe is to be assumed. While Philostratus (chap. 51) underlines the love story between Achilles and the princess, saying how she committed suicide by letting her body fall over a sword at her promised husband's grave ${ }^{46}$, Euripides' Hecabe (37 ff., 109 ff., 223 ff., 521 ff.) $)^{47}$ rests on the idea of the sacrifice demanded by the ghost of Achilles, the version that went further in time and was followed, among many others, by Quintus' Posthomerica (12.210 ff.). If, in the Posthomerica (496-508), Tzetzes worked upon Philostratus' ver-

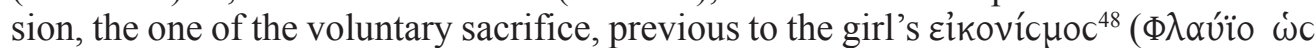

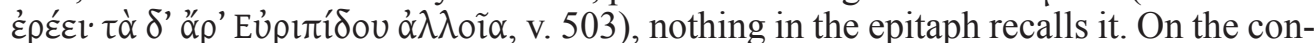
trary, Tzetzes once again in the scholium approaches both authors (

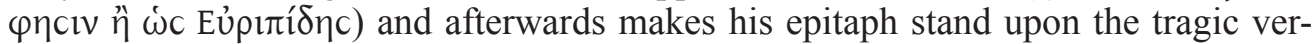

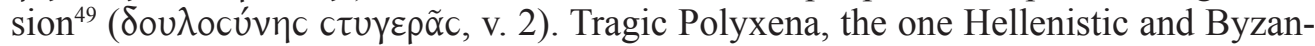
tine Greek authors preferred, must have been the one celebrated also in the lost epitaph of the Peplos, as perceived by Ausonius' replica of it (ep. $26=$ number 85), where the heroine herself concludes on her fate: "violare magis quam sepelire fuit" (v. 4).

\section{CONCLUSIONS}

The eight Tzetzian apochrypha are composed according to the structural patterns of the extant traditional couplets. Apart from the one on Troilus (number $35=$ number 91) - whose pentameter, transmitted by a single manuscript (Leone's L), must be an addition of its anonymous scribe - , all of them are elegiac couplets and provide little

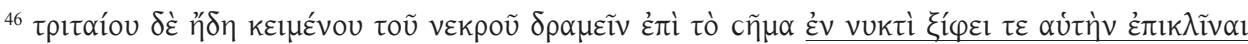

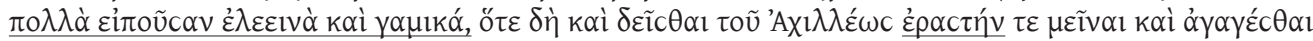

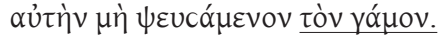

${ }^{47}$ Cf. Tro. $39 \mathrm{ff}$.

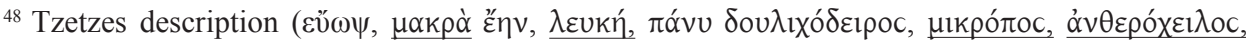
$\kappa \alpha \lambda \lambda i ́ \mu \alpha c \tau o c, \dot{\alpha} \rho i ́ c \tau \eta \cdot$, vv. 507-508) is actually very close to the one found in Isaac Porphyrogenetes

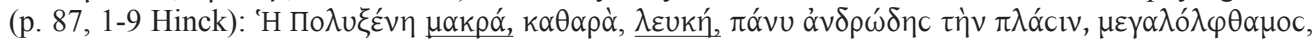

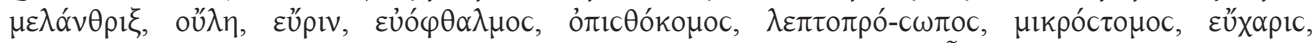

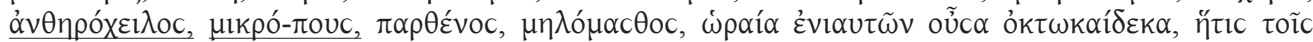

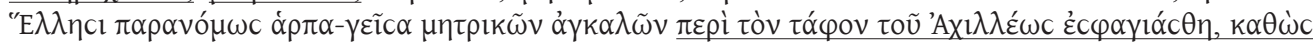

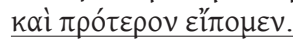

${ }^{49}$ The same one he explains in schol. in Lycophr. 323, mentioning Hecabe and Trojan Women. 
more than the essential information: the name of the deceased, his ancestry, his burial place and, in some cases, some personal feature and the cause of death ${ }^{50}$. Tzetzes shows to be aware of the ultimate origin of this kind of epitaphs, namely their inscription or, at most cases, the fiction of it. Nonetheless, while experimenting the patterns of both third and first person enunciation, there is a clear preference for the last one. More specifically, the deceased's enunciation is the most frequent, as in the case of Palamedes (number $31=$ number 87), Polydamas (number $34=$ number 90), Antilochus (number $36=$ number $\mathbf{9 2}$ ) and Polyxena (number 37 = number 93), with only two examples providing the tombstone's voice (Euphorbus and Troilus) ${ }^{51}$. As for metrics ${ }^{52}$, Tzetzes' apochrypha have four hexameters with none of the traditional third-foot caesurae $(\mathbf{8 7 . 1}, \mathbf{9 0 . 1}, \mathbf{9 1 . 1}$, and 93.1), and four other with the masculine caesura (86.1, 88.1, 89.1 and 92.1) - even if 89.1, as printed here, is the result of Jac.'s correction and, as transmitted by $\mathbf{H}$, does not fit the metrics of the hexameter. Such a ratio must be due to his attempts to reproduce Homeric rhythm and diction, but still agrees with the ratio of the traditional epigrams of the Peplos, $71 \%$ of which have the same caesura. While scholars recognised long time ago Tzetzes' discomfort with classical metrical rules of the hexameter (e.g. Platt 1890: 168-169), recent authors as Kaldellis (2007: 304) consider that "he could imitate Homeric verse fairly well" he is proud of ${ }^{54}$ and was actually required for a task like the one of composing the Carmina Iliaca.

As for the position of the Peplos' epitaphs in Tzetzes' sources, I believe to have showed that he made use of more than one codex, among the several available from the fourth century AD onwards, and by which the epitaphs, already detached from the original 'Aristotelian' work, managed to have a huge circulation. Secondly, that the copy of 37 epitaphs in the Scholia, performed over sources other than the ones used by the scribe of La, a century later, is to be seen as another example of Tzetzes' erudition, of his wish to provide students of Homer with the most possible literary information on the subject. Finally, that the eight apochrypha he composed, thematically and structurally dependent on the traditional extant epitaphs he knew, besides proving his commitment to Homeric diction and metrics, are also capable of illustrating his way of approaching Greek myth, in between the obedience to sources and the very "fabrication of myths". Tzetzes' Carmina and Scholia — and the epitaphs among the last ones are, in a word, more than commentaries of Homer. They are, by themselves, a way of rewriting Homer.

${ }^{50}$ For a summary of the traditional epitaphs' structure see Martins de Jesus (2015: 20-22).

${ }^{51}$ By doing so, Tzetzes' apochrypha somehow detach themselves from the tradition of the more ancient epitaphs ascribed to the Peplos, where 63 out of 73 epigrams prefer third-person enunciation and only ten are enunciated by a first person.

${ }_{52}^{52}$ For the metrics of the Pepli Epitaphia, namely of the hexameter, see Martins de Jesus (2015: 25-26).

${ }^{53}$ Apud Basilikopoulou-Ioannidou (1971-1972: 121-122).

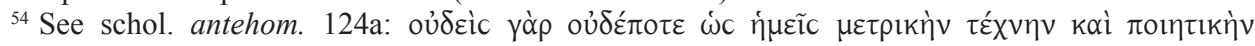

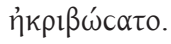




\section{BIBLIOGRAPHY}

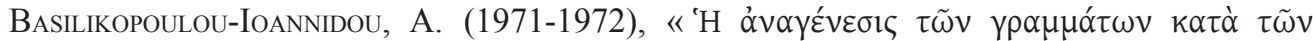

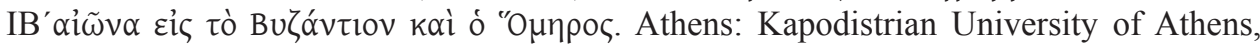
School of Philosophy.

Bergk, T. (1882), Poetae Lyrici Graeci. Vol. II. Leipzig.

Braccini, Tommaso (2010), «Mitografia e miturgia femminile a Bisanzio: il caso di Giovanni Tzetze», I Quaderni del Ramo d'Oro 3: 88-105.

- (2009-2010), «Erudita invenzione: riflessioni sulla Piccola grande Iliade di Giovanni Tzetze», Incontri triesteni di filologia clasica 9: 153-173.

- (2011), «Riscrivere l'epica: Giovanni Tzetze di fronte al ciclo troiano», CentoPagine 5: 43-57.

Browning, R. (1975), «Homer in Byzantium», Viator 8: 15-33.

— (1992), «The Byzantines and Homer», en R. Lamberton, J. J. Keaney (eds.), Homer's Ancient Readers. Princeton: 134-148.

Budelmann, F. (2002), «Classical commentary in Byzantium: John Tzetzes on ancient Greek literature», en R. K. Gibson, C. S. Kraus (eds.), The Classical Commentary. Histories, practices, theory. Brill, Leiden, Boston, Köln: 141-169.

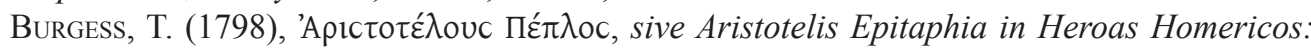
fragmentum ab $H$. Stephano primum editum, nunc pluribus avetum epitaphiis, partim nuper editis, partim nunc primum e codice Harleiano. Ed. C. G. Heyne. Denelmiae.

Cameron, A. (1993), The Greek Anthology: from Meleager to Planudes. Oxford: 388-393.

- (2004), Greek Mythography in the Roman World. Oxford.

Dragon, G. (2005), «Byzance et la Grèce antique: un impossible retour aux sources», Cahiers de la Villa Kérylos 16.1: 195-206.

- (2007), Décrire et peindre. Essai sur le portrait iconique. Paris.

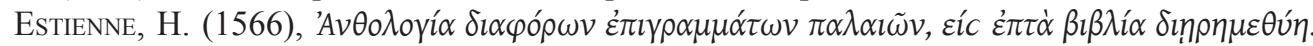
Paris: 497-502.

- (1573), Homeri et Hesiodi certamen. Nunc primum luce donatum. Matronis et aliorum parodiae, ex Homeri versibus parua immutatione lepide detortis consutae. Homericorum heroum epitaphia. Cum duplici interpretatione latina. Geneva.

Di Giovine, C. (1998), «Ausonio e i modelli greci. Note a epit. 1-3 Green», Bollettino di Studi Latini 28: 461-466.

- (1999), «Note agli Epitaphia di Ausonio», in Annali della Facoltà di Lettere e Filosofia Univ. Basilicata 9 (= Scritti in memoria di Giacomo Bona): 113-122.

- (2000), «Ausonio e i modelli greci. Nota a epit. 7 Green (Antilocho)», in Letteratura e riflessione sulla letteratura nella cultura classica. Atti del Convegno. Pisa, 7-9 giugno 1999. Pisa: 235-240.

Gow, A. S. F., Page, D. L. (1965), The Greek Anthology. Hellenistic Epigrams. Vol. I Introduction, text, and indexes o sources and epigrammatists; Vol. II Commentary and indexes. Cambridge. $[H E]$

Green, R. P. H. edd (1999), Decimi Magni Ausonii Opera. Oxford.

Gutzwiller, K. (2010), «Heroic epitaphs of the classical age: the Aristotelian Peplos and beyond», in M. Baumbach (et alii, edd.), Archaic and Classical Greek Epigram. Cambridge: 219-249. 
Heylbut, G. (1892), Eustratii et Michaelis et Anonyma in ethica Nicomachea commentaria. Berlin.

Hinck, H. (1873), Polemonis declamationes quae extant duae... Lypsig: 58-88.

Kaldellis, A. (2007), Hellenism in Byzantium. The Transformations of Greek Identity and the Reception of the Classical Tradition. Cambridge and New York.

Leone, P. A. M. (1984), «I Carmina Iliaca di Giovanni Tzetzes», Quaderni Catanesi di Studi Classici e Medievali 6: 377-405.

- (1985), «Noterelle Tzetziane (III)», Quaderni Catanesi di Studi Classici e Medievali 7: 293-309.

Leone, P. L. M. (1995), Ioannis Tzetzae Carmina Iliaca. Catania.

Maltese, E. V. (2006), Dimensioni bizantine. Donne, angeli e demoni nel Medievo greco. Alessandria.

Martínez Manzano, T. (1994), Konstantinos Laskaris. Humanist, Philologe, Lehrer, Kopist. Hamburg.

- (1998), Constantino Láscaris. Semblanza de un humanista bizantino. Madrid.

Martins de Jesus, C. A. (2015), Epitaphs for the heroes. Pepli Epitaphia (Appendix Planudea). Introduction, text, and commentary. Berlin, Logos Verlag.

Matzukis, C. (1992), «Homer within the Byzantine framework», Akroterion 37.1: 2-5.

Moraux, P. (1951), Les Listes anciennes des ouvrages d'Aristote. Louvain.

Morgan, G. (1983), «Homer in Byzantium: John Tzetzes», en C. A. Rubio, C. W. Shelmerdine (eds.), Approaches to Homer. Austin: 165-168.

Morelli, A. M. (2013), «Le statut littéraire des Epitaphia heroum d'Ausone», en M.-F. Guipponi-Ginest, C. Urlacher-Becht (eds.), La Renaissance de l'Épigramme dans la Latinité Tardive. Paris: 75-88.

Platt, A. (1890), «On the iambic trimeter», Journal of Philology 18: 161-180.

Ronckey, S. (2002), «La Femme Fatale bizantina», Paleoslavica 10.2: 103-115.

Rose, V. (1863), Aristotelis pseudoepigraphus. Leipzig.

- $\left({ }^{3} 1886\right.$, repr. 1967.), Aristotelis qui ferebantur librorum fragmenta. Berlin.

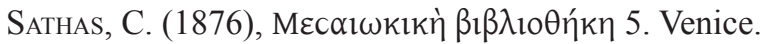

Schirach, G. B. (1770), Ioannis Tzetzae Carmina Iliaca, nunc primum e codice August edidit. Hale.

Schneidwin, F. W. (1846), «De Peplo Aristotelis Stagiritae. Accedunt pepli reliquiae», Philologus 1: 1-45.

VAN DER VALK, M. edd. (1971-1987), Eustathii archiepiscopi Thessalonicensis Commentarii ad Homeri Iliadem pertinentes (4 vols.). Leiden.

Wendling, A. (1891), De Peplo Aristotelico quaestiones selectae (diss.). Strasbourg. 


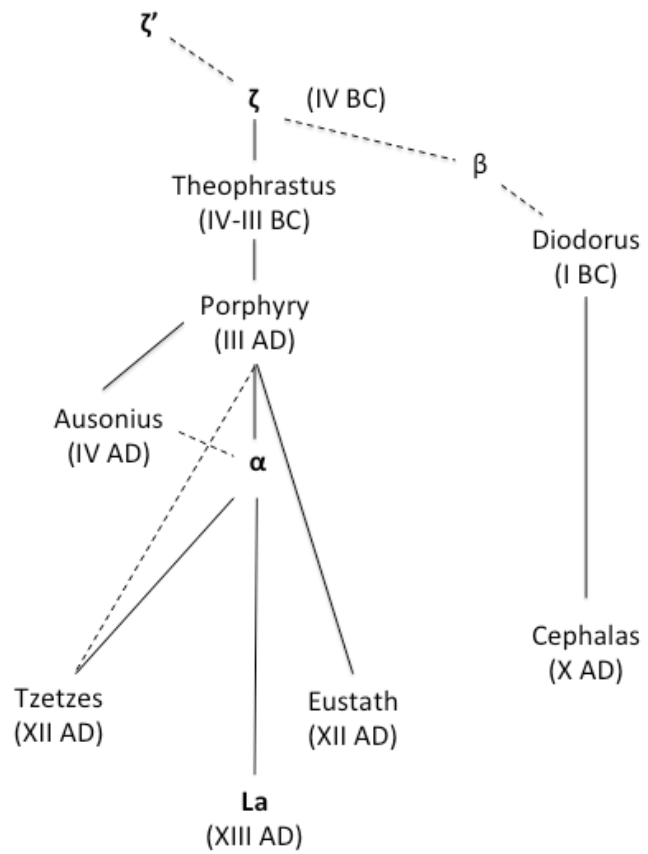

Picture 1. Stemma for the transmission of the Pepli Epitaphia. 
Miresequa is sipaugses'cura incóvágoes nitertla.

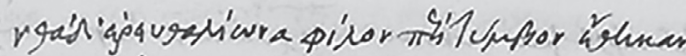

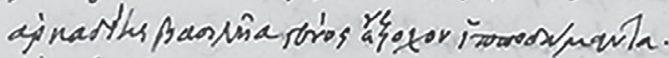

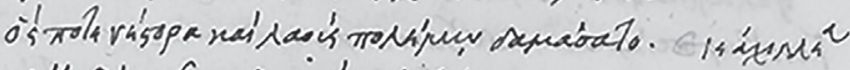

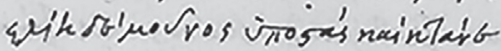

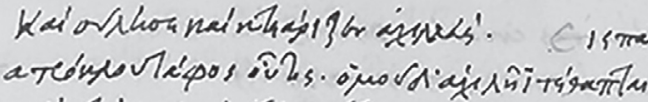

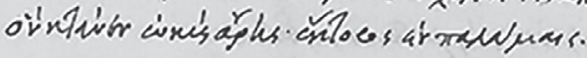

is dounionr cirrios dopunsiá. Tap orita.

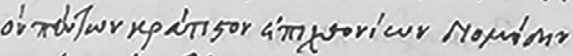

hisiapáraláts rñoss opewrupach.

is otrajar naliupuacer

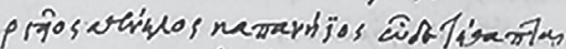

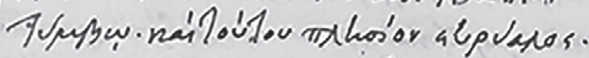

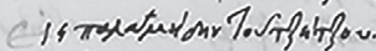

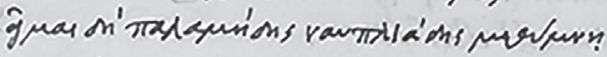

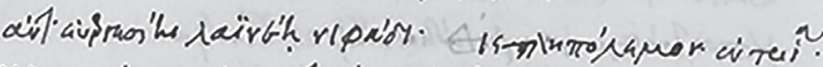

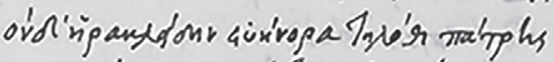

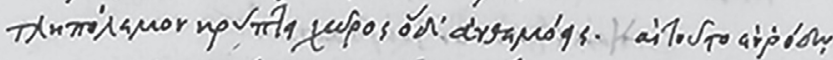

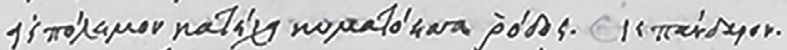

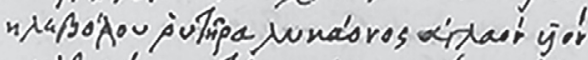

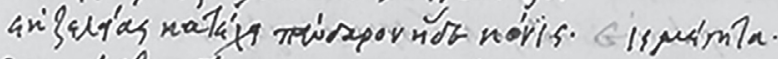

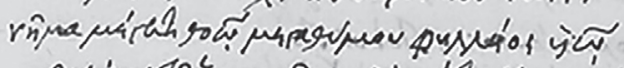

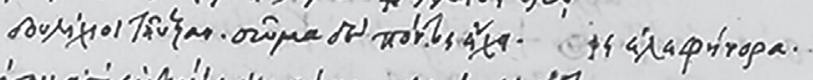

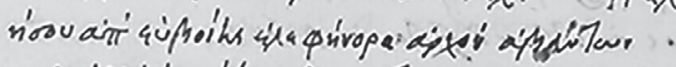

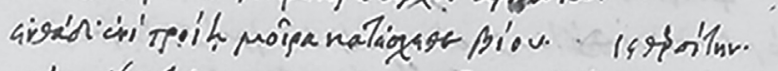

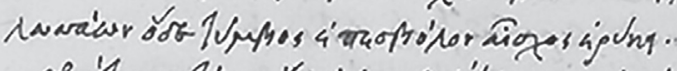

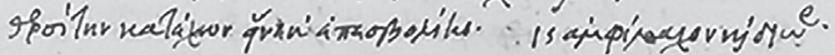

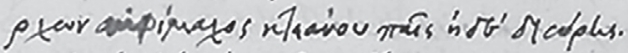

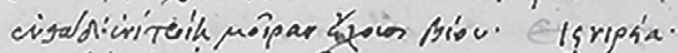

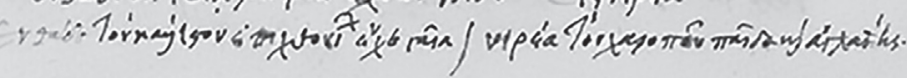

Picture 2. Matritensis gr. 4562 (M), fol. $127 \mathrm{v}$.

Reproduction authorized by the National Library of Spain. 


\begin{tabular}{|c|c|c|c|c|c|c|}
\hline$\#$ & Jesus & Rose & Source & Hero & M & Md \\
\hline 1 & 4 & 4 & La, Posthom. $465^{2}$ & Achilles (1) & & \\
\hline 2 & 5 & 5 & La, Posthom. $465^{1}$ & Achilles (2) & & \\
\hline 3 & 6 & 6 & La, Hom. $220^{3}$ & Patroclus & $*$ & \\
\hline 4 & 7 & 7 & $\begin{array}{l}\text { La, Posthom. } 489 \\
\text { Eust. Il.2.557 }\end{array}$ & Ajax Telamonian (1) & $*$ f. $126 \mathrm{r}$ & \\
\hline 5 & 14 & 14 & La, Hom. $113 b^{2}$ & Diomedes & $*$ & $*$ \\
\hline 6 & 16 & 16 & La Antehom. 300a & Ajax (son of Oileus) & & \\
\hline 7 & 17 & 17 & La, Antehom. $278 \mathrm{a}^{1}$ & Nireus & $*$ & $*$ \\
\hline 8 & 18 & 18 & La, Hom. 91 $\mathrm{a}^{2}$ & Tlepolemus (1) & $*$ & $*$ \\
\hline 9 & 23 & 23 & La, Hom. $42 \mathrm{~b}^{3}$ & Thoas & $*$ & \\
\hline 10 & 25 & 25 & La, Hom. 59a & Meges & $*$ & $*$ \\
\hline 11 & 31 & 31 & La, Hom. $42 b^{1}$ & Amphimacus \& Diores & $*$ & \\
\hline 12 & 33 & 33 & La, Hom. 38 & Elephenor & $*$ & \\
\hline 13 & 35 & 35 & La, Hom. $113 b^{3}$ & Sthenelus \& Euryalus & $*$ & $*$ \\
\hline 14 & 46 & 46 & La, Hom. $489^{2}$ & Hector $(1)$ & $*$ f. $127 \mathrm{r}$ & $*$ \\
\hline 15 & 49 & 49 & Antehom. 247 & Protesilaus & $*$ f. $125 \mathrm{v}^{\mathrm{m}}$ & \\
\hline 16 & 50 & 50 & Antehom. $257 \mathrm{a}$ & Cycnus & $*$ & $*$ \\
\hline 17 & 51 & 51 & Hom. $42 \mathrm{~b}^{2}$ & Peirous \& Acamas & $*$ & \\
\hline 18 & 52 & 52 & Hom. 69b & Pandarus & $*$ & $*$ \\
\hline 19 & 53 & 53 & Hom. 71a & Aeneas & $*$ & $*$ \\
\hline 20 & 54 & 54 & Hom. 85b & Pylaemenus & $*$ & $*$ \\
\hline 21 & 55 & 55 & Hom. 91 $\mathrm{a}^{1}$ & Tlepolemus (2) & $*$ & $*$ \\
\hline 22 & 56 & 56 & Hom. 190a & Dolon & & \\
\hline 23 & 57 & 57 & Hom. 190b & Rhesus & $*$ & \\
\hline 24 & 58 & 58 & Hom. $220^{1}$ & Sarpedon & $*$ & \\
\hline 25 & 59 & 59 & Hom. $220^{2}$ & Glaucus & $*$ & \\
\hline 26 & 60 & 60 & Hom. $489^{1}$ & Hector (2) & $*$ f. $127 \mathrm{r}$ & $*$ \\
\hline 27 & 61 & 61 & Posthom. $207^{1}$ & Penthesileia & $*$ & $*$ \\
\hline 28 & 62 & 62 & Posthom. $334^{1}$ & Memnon & $*$ & $*$ \\
\hline 29 & 63 & 63 & Posthom. 595 & Alexander (Paris) & $*$ & - \\
\hline 30 & 86 & - & Antehom. $278 \mathrm{a}^{2}$ & Hiera & $*$ & $*$ \\
\hline 31 & 87 & - & Antehom. 406b & Palamedes & $*$ & \\
\hline 32 & 88 & - & Hom. 223a & Euphorbus & $*$ & $*$ \\
\hline 33 & 89 & - & Posthom. $207^{2}$ & Thersites & $*$ & $*$ \\
\hline 34 & 90 & - & Posthom. 347 & Polydamas & $*$ & $*$ \\
\hline 35 & 91 & - & Posthom. 385b & Troilus & & $*$ \\
\hline 36 & 92 & - & Posthom. 477 & Antilocus & & \\
\hline 37 & 93 & - & Posthom. 508b & Polyxena & & \\
\hline
\end{tabular}

Table 1. The epitaphs copied by Tzetzes in the Scolia to the Carmina Iliaca. 